\title{
Penurunan COD dan Deterjen pada Saluran Kalidami Kota Surabaya dengan Oksidator $\mathrm{H}_{2} \mathrm{O}_{2}$ dan $\mathrm{KMnO}_{4}$
}

\author{
Waninda Aji Wulandari dan Eddy Setiadi Soedjono \\ Departemen Teknik Lingkungan, Fakultas Teknik Sipil dan Perencanaan, Institut Teknologi Sepuluh Nopember (ITS) \\ Jl. Arief Rahman Hakim, Surabaya 60111 Indonesia \\ e-mail:Soedjono@enviro.its.ac.id
}

\begin{abstract}
Abstrak-Deterjen memiliki kemampuan untuk menghilangkan berbagai kotoran yang menempel pada kain, alat-alat rumah tangga, dan peralatan lainnya. Oleh karena itu, deterjen masuk ke badan air sebagai buangan rumah tangga atau sering disebut dengan limbah domestik. Air yang penuh dengan limbah deterjen mengalir menuju hilir dan berkumpul pada ujung rumah pompa. Kemudian saat rumah pompa beroperasi, turbulensi dari pompa yang ada menyebabkan terbentuknya buih yang melimpah yang dapat menutupi badan air. Penelitian ini menggunakan hidrogen peroksida $\left(\mathrm{H}_{2} \mathrm{O}_{2}\right)$ dan Kalium Permanganat $\left(\mathrm{KMnO}_{4}\right)$ sebagai oksidator penurun senyawa organik dan deterjen. Penelitian ini dilakukan pada salah satu rumah pompa yang ada di kota Surabaya yaitu Rumah Pompa Boezem Kalidami. Pengambilan sampel dilakukan pada inlet rumah pompa Boezem Kalidami. Dalam penelitian dilakukan dua variasi berbeda yaitu dosis dari oksidator yaitu $\mathrm{KMnO}_{4}$ dan $\mathrm{H}_{2} \mathrm{O}_{2}$ dan pH pada sampel yang diuji. Jenis hidrogen peroksida yang digunakan adalah hidrogen peroksida teknis dengan kadar $50 \%$, masing-masing sebanyak $0,1 \mathrm{~mL}, 0,2 \mathrm{~mL}$ dan $0,3 \mathrm{~mL}$ sedangkan variasi penambahan $\mathrm{KMnO}_{4}$ sebanyak $0,6 \mathrm{~mL}, 0,65 \mathrm{~mL}$ dan 0,70 $\mathrm{mL}$. Nilai penyisihan COD dan surfaktan dengan menggunakan oksidator $\mathrm{H}_{2} \mathrm{O}_{2}$ optimum pada saat dosis penambahan $0,1 \mathrm{~mL}$ dengan $\mathrm{pH}$ netral hingga didapatkan nilai penyisihan COD sebesar $53 \%$ dan penyisihan LAS dan ABS masing-masing sebesar 39\% dan 33\%. Nilai penyisihan $\mathrm{COD}$ dengan menggunakan oksidator $\mathrm{KMnO}_{4}$ optimum pada saat penambahan $0,65 \mathrm{~mL}$ dengan $\mathrm{pH}$ netral sehingga didapatkan nilai COD sebesar $58 \%$ dan penyisihan nilai surfaktan berada pada penambahan dosis $0,6 \mathrm{~mL}$ pada $\mathrm{pH}$ netral dengan nilai penyisihan LAS dan ABS masing-masing sebesar 53\% dan $45 \%$.
\end{abstract}

Kata Kunci- LAS, ABS, $\mathrm{KMnO}_{4}, \mathrm{H}_{2} \mathrm{O}_{2}, \mathrm{COD}$

\section{PENDAHULUAN}

A KTIVITAS manusia yang secara sengaja ataupun tidak sengaja dalam membuang limbahnya ke perairan dapat menambah kandungan bahan organik, ataupun bahan nonorganik yang dapat mencemari perairan. Deterjen memiliki kemampuan untuk menghilangkan berbagai kotoran yang menempel pada kain, alat-alat rumah tangga, dan peralatan lainnya. Oleh karena itu, deterjen masuk ke badan air sebagai buangan rumah tangga atau sering disebut dengan limbah domestik. Penggunaan deterjen bersifat kontinyu (terus menerus) dan menyebabkan ketergantungan. Limbah deterjen bertambah seiring dengan bertambahnya jumlah penduduk. Limbah ini membuat permukaan badan air tertutup busa.

Dengan semakin meningkatnya pemakaian bahan berkandungan deterjen oleh masyarakat atau industri, maka makin meningkat pula potensi pencemaran yang diakibatkan oleh buangan yang mengandung deterjen tersebut. Keberadaan deterjen dalam air semakin meningkat sehingga menjadi lebih tinggi dari ambang batas yang telah ditentukan akan mengakibatkan menurunnya kualitas air, yang pada akhirnya akan berakibat pada kualitas kesehatan masyarakat. Oleh karena itu, sesuai dengan PP No. 82 Tahun 2001 Tentang Pengelolaan Kualitas Air dan Pengendalian Pencemaran Air Kelas III bahwa kandungan deterjen dalam air limbah tidak boleh melebihi $0,2 \mathrm{mg} / \mathrm{L}$.

Deterjen yang dijual bebas di pasaran biasanya mengandung $20-40 \%$ surfaktan, sedangkan sisanya adalah bahan kimia yang biasanya disebut dengan additivies atau deterjen builders yang berfungsi untuk meningkatkan daya bersih deterjen. Bahan surfaktan yang biasa digunakan adalah alkyl benzene (ABS). Senyawa ini termasuk dalam senyawa non biodegradable yaitu tidak dapat didegradasi oleh mikroorganisme, dan juga banyak menimbulkan busa baik pada sungai ataupun air tanah [1]. Akumulasi deterjen dalam perairan dapat meningkatkan nilai kandungan Chemical Oxygen Demand (COD)/kebutuhan oksigen kimiawi, Biologycal Oxygen Demand (BOD)/ kebutuhan oksigen biologi, dan angka permanganate.

Air yang penuh dengan limbah deterjen mengalir menuju hilir dan berkumpul pada ujung rumah pompa. Kemudian saat rumah pompa beroperasi, turbulensi dari pompa menyebabkan terbentuknya buih yang melimpah yang dapat menutupi badan air. Kasus ini banyak terjadi pada rumah pompa yang ada di Kota Surabaya, salah satu contohnya yang terjadi di Rumah Pompa Boezem Kalidami.

Saluran Kalidami merupakan muara dari 3 bagian yaitu, bagian utara berasal dari daerah Baskarasari, Mulyosari, dan Dharmahusada, pada bagian selatan berbatasan dengan Kejawan, Keputih, ITS dan Gebang, serta pada bagian barat berasal dari Kalidami, Kertajaya dan Manyar Sabrangan.

Pengolahan air limbah yang mengandung surfaktan detergen yang disarankan oleh beberapa buku teks adalah 
proses koagulasi dan sedimentasi, flotasi dan adsorpsi dengan menggunakan karbon aktif ${ }^{[2]}$. Namun pada penelitian kali ini akan dilakukan percobaan pengurangan kandungan bahan organik dan buih yang berasal dari deterjen menggunakan Hidrogen peroksida $\left(\mathrm{H}_{2} \mathrm{O}_{2}\right)$ dan Kalium Permanganat $\left(\mathrm{KMnO}_{4}\right)$.Hidrogen peroksida merupakan senyawa oksidator kuat yang dapat dikatakan ramah lingkungan. Hidrogen peroksida sendiri biasa berbentuk cairan yang yang tidak berwarna dan mudah larut dalam air. Hidrogen peroksida di sisi lain, hanyalah air dengan molekul oksigen tambahan dan akan terurai menjadi oksigen dan air.

Namun, terdapat oksidator kuat lainnya yang digunakan dalam penelitian ini, yaitu kalium Permanganat $\left(\mathrm{KMnO}_{4}\right)$.

Kalium permanganat atau $\mathrm{KMnO}_{4}$ adalah garam yang tidak tersedia di alam. Sebenarnya, itu dihasilkan dari $\mathrm{MnO}_{2}$ yang disatukan dengan $\mathrm{KOH}$ dan nya. $\mathrm{MnO}^{4-}$ adalah oksidan kuat, dimana $\mathrm{Mn}$ memiliki keadaan oksidasi +7 yang dimilikinya tinggi pe pada $\mathrm{pH}$ rendah. $\mathrm{pH}$ sangat mempengaruhi potensi redoks $\mathrm{KMnO}_{4}$, untuk diketahui bahwa oksidasi $\mathrm{KMnO}_{4}$ akan menghasilkan $\mathrm{Mn}$ dalam berbagai keadaan oksidasi $\left(\mathrm{Mn}^{6+}\right.$, $\mathrm{Mn}^{5+}, \mathrm{Mn}^{4+}, \mathrm{Mn}^{3+}, \mathrm{Mn}^{2+}$ ) tergantung pada reaktan dan $\mathrm{pH}$ sistem. Potensi redoks di bawah berbeda tergantung pada kondisi $\mathrm{pH}$, seperti dijelaskan di bawah ini:

Dalam larutan asam kuat:

$$
\begin{array}{lll}
\mathrm{MnO}^{4-}+8 \mathrm{H}^{+}+5 \mathrm{e}^{-} & \mathrm{Mn}^{2+}+4 \mathrm{H}_{2} \mathrm{O} & \mathrm{Eo}=1,51 \mathrm{~V} \\
\text { Dalam larutan alkali: } & & \\
\mathrm{MnO}^{4-}+2 \mathrm{H}_{2} \mathrm{O}+3 \mathrm{e}^{-} & \mathrm{MnO}_{2(\mathrm{~s})}+4 \mathrm{OH}^{-} & \mathrm{Eo}=0,59 \mathrm{~V} \\
\text { Dalam pH netral asam: } & & \\
\mathrm{MnO}^{4-}+4 \mathrm{H}^{+}+3 \mathrm{e}^{-} & \mathrm{MnO}_{2(\mathrm{~s})}+2 \mathrm{H}_{2} \mathrm{O} & \mathrm{Eo}=1,70 \mathrm{~V}
\end{array}
$$

$\mathrm{KMnO}_{4}$ diketahui mudah mengoksidasi ikatan rangkap karbon karbon alkena dan berpotensi mengoksidasi ikatan rangkap aromatik [3].

\section{A. Metode Penelitian}

Penelitian dilakukan dalam skala laboratorium dan dilaksanakan di Laboratorium Teknologi Pengolahan Air Jurusan Teknik Lingkungan FTSP ITS Surabaya. Limbah berasal dari inlet Rumah Pompa Boezem Kalidami. Sampel yang digunakan adalah sampel asli. Metode yang digunakan adalah pengadukan cepat dengan prisip jar test dalam keadaan batch dalam gelas beaker $1 \mathrm{~L}$. Selanjutnya dilakukan analisis COD dan perhitungan analisis MBAS untuk mengetahui kandungan LAS dan ABS.

\section{B. Penelitian Pendahuluan}

Pada Penelitian pendahuluan dilakukan penelitian dengan sampel air baku untuk menentukan dosis yang akan digunakan pada penelitian utama. Penentuan dosis penelitian ini dilakukan dengan penambahan $0,1 \mathrm{mg} / \mathrm{L}, 0,3 \mathrm{mg} / \mathrm{L} .0,5 \mathrm{mg} / \mathrm{L}$, $0,7 \mathrm{mg} / \mathrm{L}$, dan $0,9 \mathrm{mg} / \mathrm{L}$ masing-masing oksidator. Selanjutnya menentukan kecepatan dari Jar Test yang akan digunakan. Pada penelitian pendahuluan ini, kecepatan dilakukan dari rentang yang besar 10-100 rpm hingga didapatkan kecepatan pengadukan paling optimum. Begitu pula dengan penelitian pendahuluan terhadap lamanya pengadukan. Pada oksidator $\mathrm{H}_{2} \mathrm{O}_{2}$ dilakukan penelitian selama 1 menit, 2 menit, 3 menit, 5 menit dan 10 menit sedangkan untuk oksidator $\mathrm{KMnO}_{4}$ penelitian dilakukan selama 15 menit hingga 2 jam. Masingmasing penentuan optimum dari penelitian pendahuluan dilihat dari penyisihan COD pada air limbah yang paling besar.

\section{Penelitian Utama}

Pada penelitian utama dilakukan pengkondisian limbah dalam kondisi $\mathrm{pH}$ berbeda yaitu 3,7 dan 9 dengan masingmasing variasi penambahan dosis $\mathrm{H}_{2} \mathrm{O}_{2}$ dari hasil penelitian pendahuluan dengan rentang telah dipersempit yaitu 0,1 $\mathrm{mL} / \mathrm{L}, 0,2 \mathrm{~mL} / \mathrm{L}$ dan $0,3 \mathrm{~mL} / \mathrm{L}$. Penelitian ini dilakukan dengan kecepatan pengadukan sebesar 70 rpm dalam 5 menit.

Sedangkan pada penelitian pendahuluan menggunakan $\mathrm{KMnO}_{4}$ sebelumnya, dosis optimum didapatkan $0,7 \mathrm{mg} / \mathrm{L}$ sehingga dilakukan dalam rentang dosis $0,6 \mathrm{mg} / \mathrm{L}, 0,65 \mathrm{mg} / \mathrm{L}$ dan $0,7 \mathrm{mg} / \mathrm{L}$. Pada penelitian ini limbah pada kondisi awal dikondisikan dalam variasi $\mathrm{pH}$ berbeda, masing-masing dengan $\mathrm{pH}$ 3, 7 dan 9. Penelitian dilakukan dengan pengadukan dengan kecepatan $90 \mathrm{rpm}$ dan waktu pengadukan selama 30 menit, serta waktu pengendapan 30 menit.

\section{HASIL DAN PEMBAHASAN}

\section{A. Karakteristik Limbah Awal}

Air limbah domestik yang digunakan pada penelitian ini diambil dari inlet pada Rumah Pompa Boezem Kalidami, Surabaya Jawa Timur. Analisis yang dilakukan pada air limbah ini diantaranya adalah pengukuran nilai COD, kandungan surfaktan anionik meliputi nilai LAS dan ABS, serta $\mathrm{pH}$. Analisis dilakukan sebanyak tiga kali pada pagi hari pada saat keadaan tidak hujan pada satu hari sebelumnya dan pompa sedang dijalankan. Hasil analisis awal limbah dapat dilihat pada Tabel 1 .

Tabel 1. karakteristik Limbah Awal

\begin{tabular}{ccccc}
\hline \hline day & $\mathrm{pH}$ & $\begin{array}{c}\mathrm{COD} \\
(\mathrm{mg} / \mathrm{L})\end{array}$ & $\begin{array}{c}\mathrm{LAS} \\
(\mathrm{mg} / \mathrm{L})\end{array}$ & $\begin{array}{c}\mathrm{ABS} \\
(\mathrm{mg} / \mathrm{L})\end{array}$ \\
\hline $\mathbf{1}$ & 7,44 & 160 & 9,85 & 34,25 \\
$\mathbf{2}$ & 7,62 & 164 & 5,95 & 19,54 \\
$\mathbf{3}$ & 7,58 & 160 & 12,42 & 34,75 \\
\hline \hline
\end{tabular}

Tabel diatas merupakan nilai dari pengamatan dalam 3 kali pengambilan sampel untuk masing-masing parameter. $\mathrm{pH}$ dari saluran Kalidami beradda dalam keadaan netral. Pada parameter COD didapatkan dalam tiga kali penelitian nilai rata-rata sebesar $161,33 \mathrm{mg} / \mathrm{L}$ sedangkan nilai pada rata-rata untuk LAS dan ABS adalah sebesar 9,41 mg/L dan 29,51 $\mathrm{mg} / \mathrm{L}$. Baku mutu yang digunakan pada penelitian ini yaitu Peraturan Daerah Kota Surabaya Nomor 02 Tahun 2004 Tentang Pengelolaan Kualitas Air dan Pengendalian Pencemaran Air (Lampiran I Kriteria Mutu Air Berdasarkan Kelas Air, Kelas III) masing-masing penggunaan pada parameter COD sebesar $50 \mathrm{mg} / \mathrm{L}$ dan Deterjen sebagai MBAS sebesar $200 \mathrm{mikrogram} /$ Liter.

Dapat dilihat bahwa nilai dari kandungan COD dan deterjen berada diatas ambang batas baku mutu yang telah ditetapkan oleh pemerintah Kota Surabaya. Sehingga dalam penelitian ini akan digunakan pengolahan kimiawi menggunakan oksidator kuat yaitu $\mathrm{H}_{2} \mathrm{O}_{2}$ dan $\mathrm{KMnO}_{4}$ untuk mengetahui kemampuan masing-masing oksidator dalam 
menurunkan kandungan bahan organik dalam bentuk COD dan deterjen yang ada.

Dengan sifat hidrogen peroksida yang terurai menjadi air, menyebabkan penambahan hidrogen peroksida kedalam badan air tidaklah menimbulkan dampak yang besar ${ }^{[4]} \cdot \mathrm{H}_{2} \mathrm{O}_{2}$ juga merupakan oksidan yang kuat dan dapat digunakan untuk menghasilkan radikal hidroksil (.OH) dengan reaktivitas kedua setelah fluorin. Hidrogen perroksida telah digunakan untuk mengoksidasi bahan organik dalam limbah domestik ataupun industri selama bertahun-tahun ${ }^{[5]}$.

Sedangkan Kalium permanganat mampu mengoksidasi senyawa organik yang mengandung ikatan rangkap karbonkarbon, gugus aldehid atau hidroksil. Kalium permanganat memberikan beberapa keuntungan seperti penanganan mudah, dan merupakan padatan mudah larut dan sangat efektif dalam pengolahan air dan air limbah.

\section{B. Penelitian Pendahuluan}

- Penentuan dosis penelitian

Dalam penelitian ini akan dilakukan penentuan dosis penambahan dari masing-masing reagen yaitu $\mathrm{H}_{2} \mathrm{O}_{2}$ dan $\mathrm{KMnO}_{4}$. Dalam percobaan ini dilakukan dengan penambahan $\mathrm{H}_{2} \mathrm{O}_{2}$ sebanyak $0.1 \mathrm{~mL}, 0.3 \mathrm{~mL}, 0.5 \mathrm{~mL}, 0.7 \mathrm{~mL}$ dan $0.9 \mathrm{~mL}$. Hidrogen peroksida yang digunakan dengan konsentrasi sebesar 50\%. Dilakukan pengadukan menggunakan jartest dengan kecepatan 100rpm dan waktu pengadukan selama 5 menit sehingga didapatkan hasil pada Gambar 1. sebagai berikut:

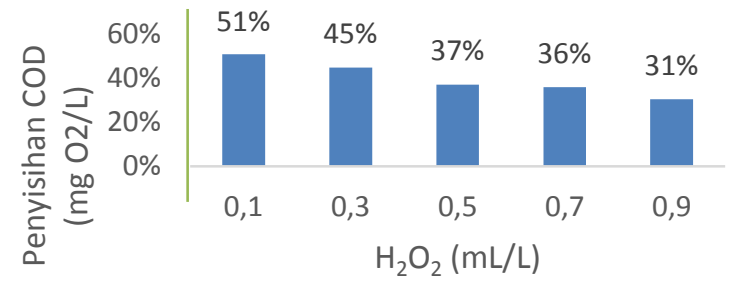

Gambar 1. Penentuan Penambahan $\mathrm{H}_{2} \mathrm{O}_{2}$

Pada Gambar 1. menunjukkan pengaruh penambahan $\mathrm{H}_{2} \mathrm{O}_{2}$ terhadap penyisihan COD. Semakin banyak penambahan $\mathrm{H}_{2} \mathrm{O}_{2}$ menyebabkan penurunan penyisihan COD. Pada Gambar 1. penambahan $\mathrm{H} 2 \mathrm{O} 2$ sebanyak $0,1 \mathrm{~mL} / \mathrm{L}$ menunjukkan penyisihan COD optimum, sedangkan pada penambahan selanjutnya sebesar $0,3 \mathrm{~mL} / \mathrm{L}$ hingga $0,9 \mathrm{~mL} / \mathrm{L}$ menghasilkan nilai penurunan efisiensi COD yang semakin menurun. Hal ini dikarenakan adanya senyawa organik ikatan rangkap yang tidak terurai secara sempurna menyebabkan terbaca sebagai nilai COD. Secara teori, penambahan $\mathrm{H}_{2} \mathrm{O}_{2}$ semakin banyak maka semakin besar penurunan COD.

Pada oksidator $\mathrm{KMnO}_{4}$ penambahan dosis dilakukan sebesar $0.1 \mathrm{mg} / \mathrm{L}, 0.3 \mathrm{mg} / \mathrm{L}, 0.5 \mathrm{mg} / \mathrm{L}, 0.7 \mathrm{mg} / \mathrm{L}$ dan 0.9 $\mathrm{mg} / \mathrm{L}$. Dilakukan pengadukan dengan kecepatan sebesar 100rpm dengan waktu pengadukan selama 30 menit dan pengendapan selama 30 menit. Dan didapatkan nilai dari penambahan $\mathrm{KMnO}_{4}$ dengan penyisihan $\mathrm{COD}$ terbesar yaitu $0,7 \mathrm{mg} / \mathrm{L}$ seperti pada Gambar 2. berikut:

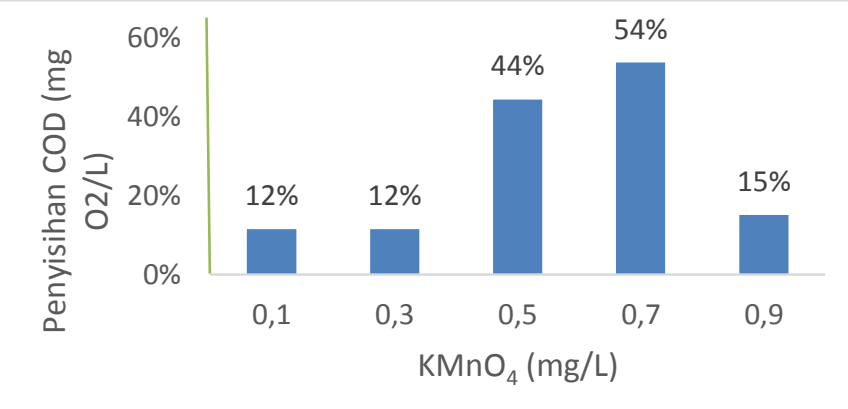

Gambar 1. Penentuan Penambahan $\mathrm{KMnO}_{4}$

Pada Gambar 2. menunjukkan nilai dari $\mathrm{KMnO}_{4}$ yang ditambahkan meningkat pada $0,5 \mathrm{mg} / \mathrm{L}$ dan optimum pada $0.7 \mathrm{mg} / \mathrm{L}$ dengan penyisihan COD sebesar $54 \%$ kemudian kembali turun pada $0.9 \mathrm{mg} / \mathrm{L}$. Hal ini disebabkan kandungan senyawa organik yang berada didalam air limbah telah terdegradasi optimum.

- Penentuan pengadukan pengolahan

Pada penentuan kecepatan pengolahan untuk $\mathrm{H}_{2} \mathrm{O}_{2}$ dilakukan pengadukan sebanyak 10 kali dengan 10 kecepatan berbeda dimulai dengan $10 \mathrm{rpm}, 20 \mathrm{rpm}, 30 \mathrm{rpm}, 40 \mathrm{rpm}$, 50rpm, 60rpm, $70 \mathrm{rpm}, 80 \mathrm{rpm}, 90 \mathrm{rpm}$ dan $100 \mathrm{rpm}$ dengan penambahan $0.1 \mathrm{~mL} \mathrm{H}_{2} \mathrm{O}_{2} 50 \%$ selama 5 menit. Berikut data yang di dapatkan terdapat pada Gambar 3. berikut:

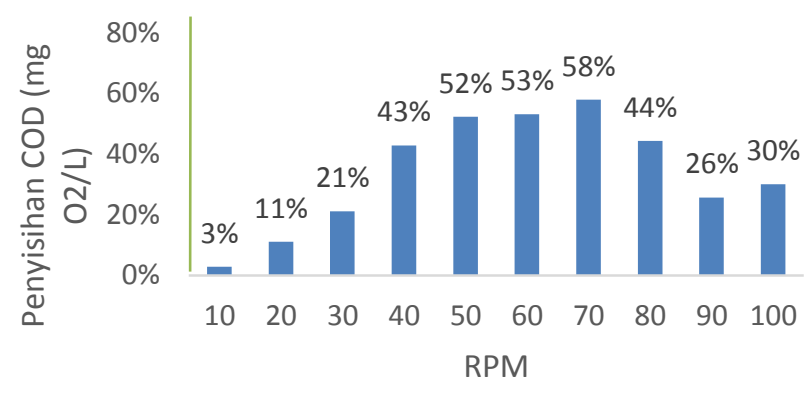

Gambar 3. Penentuan Kecepatan dengan Penambahan $\mathrm{H}_{2} \mathrm{O}_{2}$

Dari Gambar 3. diatas terlihat penyisihan COD terus meningkat pada rpm 10 hingga didapatkan nilai maksimum sebesar $58 \%$ pada $70 \mathrm{rpm}$. Selanjutnya penyisihan COD menurun pada kecepatan $80 \mathrm{rpm}$ dan 90 rpm namun kembali naik pada 100rpm. Hal ini diakibatkan oleh tumbukan antara partikel yang menyebabkan terbentuknya larutan yang homogen. Uji coba kecepatan dilakukan pada rpm rendah karena dikhawatirkan pada rpm yang tinggi dapat menyebabkan terbentuknya busa. Tujuan dari pengadukan ini adalah menentukan kecepatan optimum agar limbah dan oksidator tercampur secara homogen.

Pada $\mathrm{KMnO}_{4}$ juga dilakukan pengujian yang sama dengan variasi kecepatan $10 \mathrm{rpm}$ hingga $100 \mathrm{rpm}$ dengan penambahan $\mathrm{KMnO}_{4}$ sebanyak $0,7 \mathrm{~mL}$ dengan pengadukan 30 menit dan pengendapan selama 30 menit. Dari penelitian didapatkan tabel Removal COD seperti pada Gambar 4. berikut hingga didapatkan kecepatan optimum pada kecepatan 90rpm sebesar $44 \%$ penyisihan COD. 


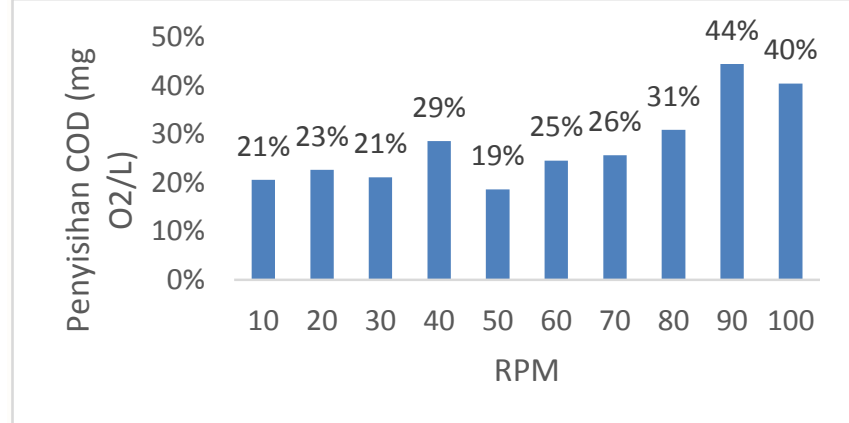

Gambar 4. Penentuan Kecepatan dengan Penambahan $\mathrm{KMnO}_{4}$

Pada Gambar 4. nilai penyisihan COD semakin meningkat pada rpm ke 40 lalu turun kembali hingga menghasilkan nilai optimum pada rpm ke 90. Hal ini dapat terjadi karena pengaruh kecepatan pengadukan dapat meningkatkan tumbukan antar molekul-molekul sehingga dapat meningkatkan terjadinya proses kimia. Pada penelitian ini hanya dibatasi hingga rpm ke 100 dikarenakan menghindarinya terbentuk busa pada sampel limbah asli yang digunakan. Laju $90 \mathrm{rpm}$ ini belum dapat dikatakan laju optimum karena penyisihan COD yang lebih besar masih mungkin diperoleh pada laju pengadukan yang lebih tinggi. Pengadukan menggunakan jartest berfungsi sebagai media pemerataan pada limbah dengan larutan oksidator yang ditambahkan.

- Penentuan waktu pengolahan

Penentuan waktu pengolahan ditentukan berdasarkan penurunan COD optimum seiring dengan lamanya waktu kontak. Pada penelitian $\mathrm{H}_{2} \mathrm{O}_{2}$ ini dilakukan pada penambahan $0,1 \mathrm{~mL} / \mathrm{L} \mathrm{H}_{2} \mathrm{O}_{2} 50 \%$ dengan kecepatan sebesar $70 \mathrm{rpm}$. Pada penelitian ini dilakukan percobaan selama 1 menit, 2 menit, 3 menit, 5 menit hingga 10 menit. Hal ini dilakukan dengan pertimbangan bahwa waktu kontak $\mathrm{H}_{2} \mathrm{O}_{2}$ terbilang cepat.

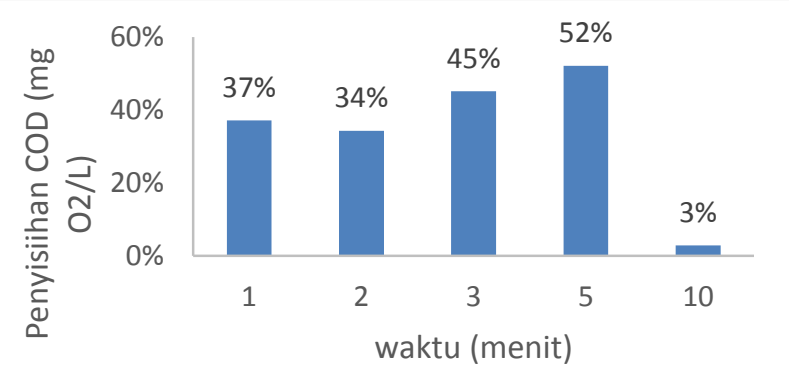

Gambar 5. Penentuan Waktu Pengolahan dengan Penambahan $\mathrm{H}_{2} \mathrm{O}_{2}$

Pada penelitian didapatkan waktu kontak optimum pada menit ke 5 dengan penurunan efisiensi hingga 52\% dan menurun secara drastis hingga menit ke 10 dengan penyisihan COD hanya 3\%. Hal ini dapat dilihat pada Gambar 5. diatas.

Hal ini diakibatkan pada fase pertama, terbentuknya hidroksil radikal dari reaksi antara $\mathrm{H}_{2} \mathrm{O}_{2}$ berlangsung sangat cepat yang selanjutnya reaksi reaksi pembentukan hidroksil radikal akan menurun seiring dengan berkurangnya $\mathrm{H}_{2} \mathrm{O}_{2}$ yang telah dikonsumsi. Dari analisis didapatkan removal tertinggi dari COD pada menit ke 5 sehingga pada penelitian utama ditentukan waktu pengadukan selama 5 menit.
Sementara itu pada penelitian $\mathrm{KMnO}_{4}$, dilakukan pengadukan menggunakan jartest dengan penambahan oksidator $\mathrm{KMnO}_{4}$ sebesar 30 menit dengan pengendapan 30 menit dengan kecepatan pengadukan sebesar $90 \mathrm{rpm}$ hingga didapatkan hasil pada Gambar 6. berikut

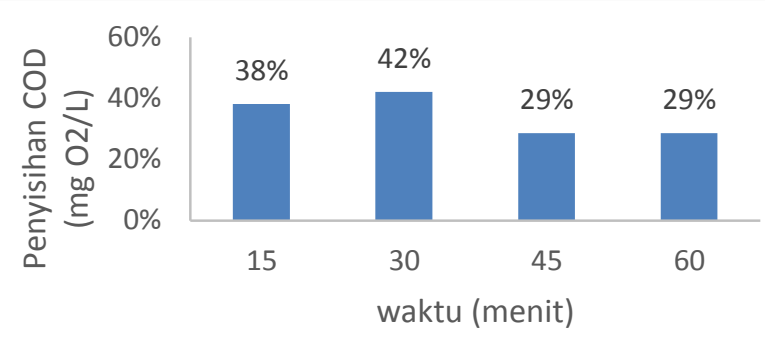

Gambar 6. Penentuan Waktu Pengolahan dengan Penambahan $\mathrm{KMnO}_{4}$

Hasil penelitian dapat dinyatakan waktu kontak optimum dari $\mathrm{KMnO}_{4}$ terdapat pada Gambar 6. berikut yaitu pada menit ke-30 dengan penyisihan COD sebesar $42 \%$. Pada menit ke 15 penyisihan COD meningkat hingga menit ke 30 mencapai $42 \%$ namun kembali turun hingga menit ke 45 dan 60 sebesar $29 \%$. Menurunnya penyisihan pada menit ke 45 hingga ke 60 diakibatkan partikel mangan okdsida yang digunakan sebagai pengoksidasi senyawa organik telah habis bereaksi ataupun sudah habisnya senyawa organik yang hendak didegradasi oleh mangan oksida, sehingga nilai penyisihan COD berkurang.

\section{Penelitian Utama}

- $\mathrm{H}_{2} \mathrm{O}_{2}$

Penurunan COD pada $\mathrm{pH}$ berbeda

Pada penelitian utama dilakukan pengkondisian limbah dalam kondisi $\mathrm{pH}$ berbeda dengan masing-masing variasi penambahan dosis $\mathrm{H}_{2} \mathrm{O}_{2}$ yang sama dengan kecepatan pengadukan sebesar $70 \mathrm{rpm}$ dalam 5 menit. Untuk mengetahui jumlah optimum $\mathrm{H}_{2} \mathrm{O}_{2}$ untuk COD removal, serangkaian percobaan telah dilakukan pada konsentrasi awal hidrogen peroksida yang berbeda. Dalam percobaan ini persentase pemindahan COD diukur selama periode reaksi 5 menit. Berikut hasil analisis penyisihan COD dapat dilihat pada Gambar 7.

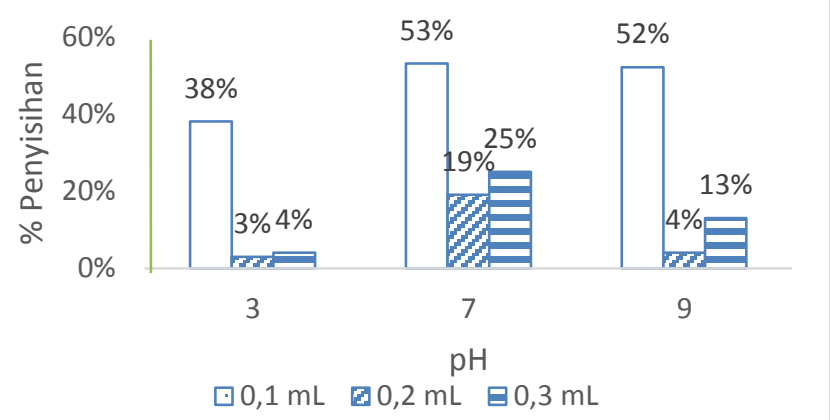

Gambar 7. Penambahan $\mathrm{H}_{2} \mathrm{O}_{2}$ terhadap Penyisihan COD dan $\mathrm{pH}$

Pada saat percobaan pada masing-masing pada $\mathrm{pH} 7$ dan 9 warna limbah setelah terjadi penambahan oksidator tetap berwarna bening sedangkan pada $\mathrm{pH} 3$ (asam) warna limbah yang telah diberikan oksidator berwarna putih susu. Hal ini 
diperkirakan menyebabkan nilai COD pada $\mathrm{pH}$ asam lebih kecil dibandingkan yang terjadi pada $\mathrm{pH}$ netral ataupun basa. tingkat kontaminasi, peningkatan dosis hidrogen peroksida dari $0,1 \mathrm{~mL} / \mathrm{L}$ sampai $0,3 \mathrm{~mL} / \mathrm{L}$ menurun pada saat penambahan dosis $\mathrm{H}_{2} \mathrm{O}_{2}$ di tiap-tiap $\mathrm{pH}$ yang dikondisikan. Jumlah $\mathrm{H}_{2} \mathrm{O}_{2}$ yang dibutuhkan akan lebih besar tergantung pada tingkat removal COD yang dibutuhkan. Dapat disimpulkan bahwa dosis $0,1 \mathrm{ml} / \mathrm{L}$ adalah dosis optimal untuk menghancurkan mayoritas produk. Namun demikian, nilai pereaksi ini melebihi $0,1 \mathrm{ml} / \mathrm{L}$ tidak memperbaiki kinerja proses.

Penurunan surfaktan pada $\mathrm{pH}$ berbeda

Penelitian selanjutnya dilakukan analisis terhadap nilai surfaktan anionik dengan menggunakan metode MBAS pada saluran Kalidami yang masing-masing limbah telah dikondisikan sesuai $\mathrm{pH}$ 3, 7 dan 9. Lalu dilakukan pengadukan menggunakan jartest selam 5 menit dengan kecepatan 70rpm. Berikut hasil penelitian dapat dilihat pada Gambar 8. dan Gambar 9.

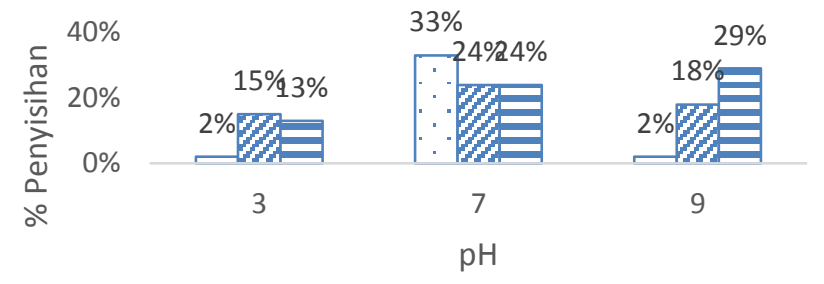

$\square 0,1 \mathrm{~mL} \quad \square 0,2 \mathrm{~mL} \quad \boxminus 0,3 \mathrm{~mL}$

Gambar 8. Penambahan $\mathrm{H}_{2} \mathrm{O}_{2}$ terhadap Penyisihan LAS dan $\mathrm{pH}$

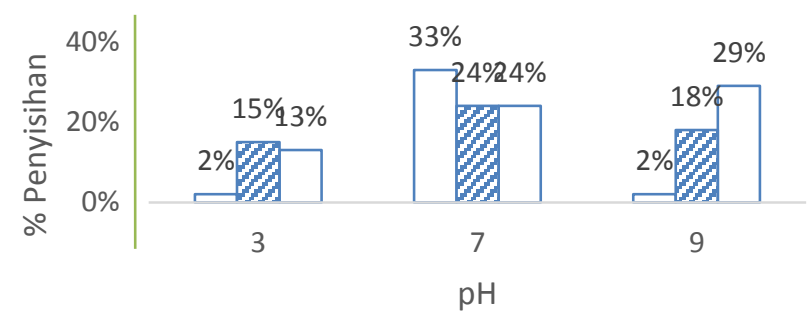

$\square 0,1 \mathrm{~mL} \quad \square 0,2 \mathrm{~mL} \quad \square 0,3 \mathrm{~mL}$

Gambar 9. Penambahan $\mathrm{H}_{2} \mathrm{O}_{2}$ terhadap Penyisihan ABS dan $\mathrm{pH}$

Pada Gambar 8. Dan Gambar 9. LAS maupun ABS nilai $\mathrm{pH}$ optimum pada percobaan didapatkan pada saat limbah mempunyai $\mathrm{pH}$ netral di saat awal. Baik LAS maupun ABS merupakan senyawa deterjen anionik yang termasuk dalam senyawa organik. Sehingga menyebabkan $\mathrm{pH}$ asam akan semakin asam setelah terjadi penambahan $\mathrm{H}_{2} \mathrm{O}_{2}$ dan menyebabkan keadaan tidak optimum lagi. Dan dibuktikan melalui persaamaan berikut, bahwa reaksi sempurna menghasilkan $\mathrm{CO}_{2}$ dan $\mathrm{H}_{2} \mathrm{O}$ pada saat netral.

Nilai deterjen yang diuji berupa surfaktan anionik yang merupakan LAS dan ABS. Reaksi antara $\mathrm{H}_{2} \mathrm{O}_{2}$ dengan deterjen: ${ }^{[6]}$. $\mathrm{a} \mathrm{C}_{12} \mathrm{H}_{25} \mathrm{NaO}_{4} \mathrm{~S}+\mathrm{b} \mathrm{H}_{2} \mathrm{O}_{2} \rightarrow \mathrm{p} \mathrm{CO} \mathrm{CO}_{2}+\mathrm{q} \mathrm{H}_{2} \mathrm{O}+\mathrm{Na}^{+}+\mathrm{S}$ (3)

Pada reaksi diatas dapat terlihat bahwa pemecahan atom $\mathrm{C}$ dalam surfaktan akan teroksidasi dengan $\mathrm{H}_{2} \mathrm{O}_{2}$ sehingga menghasilkan $\mathrm{CO}_{2}$ yang terlepas dan $\mathrm{H}_{2} \mathrm{O}$ yang akan larut dalam air yang pada akhirnya akan menurunkan kadar surfaktan. Pada reaksi ini tidak terlihat endapan setelah pengadukan menggunakankan jartest. Hal ini dikarenakan rekasi sempurna menghasilkan air, karbondioksida yang dilepaskan menjadi gas dan ion $\mathrm{Na}^{+}+\mathrm{S}^{-}$yang terlarut dalam air.

\section{- KMnO4}

Penurunan COD pada $\mathrm{pH}$ berbeda

Pada penelitian menggunakan $\mathrm{KMnO}_{4}$ sebelumnya dosis optimum didapatkan $0,7 \mathrm{mg} / \mathrm{L}$ sehingga dilakukan dalam rentang dosis $0,6 \mathrm{mg} / \mathrm{L}, 0,65 \mathrm{mg} / \mathrm{L}$ dan $0,7 \mathrm{mg} / \mathrm{L}$. Pada penelitian ini limbah pada kondisi awal dikondisikan dalam variasi $\mathrm{pH}$ berbeda, masing-masing dengan $\mathrm{pH} \mathrm{3,7}$ dan 9 . Penelitian dilakukan dengan pengadukan dengan kecepatan 90 rpm dan waktu pengadukan selama 30 menit, serta waktu pengendapan 30 menit. Hasil penelitian dapat dilihat pada Gambar 10. berikut:

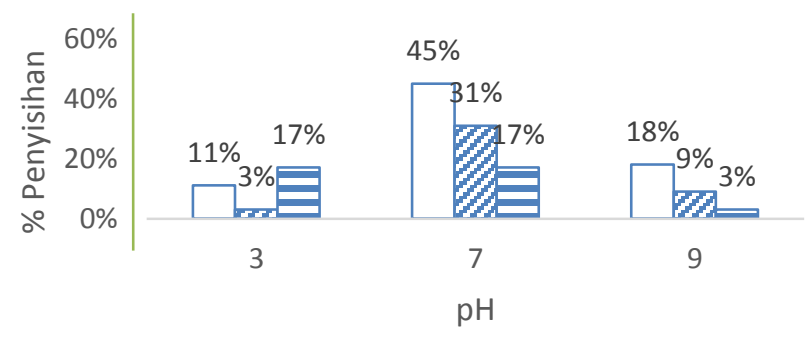

\section{$\square 0,6 \square 0,65 \square 0,7$}

Gambar 10. Penambahan $\mathrm{KMnO}_{4}$ terhadap Penyisihan COD dan $\mathrm{pH}$

Pada gambar penambahan $\mathrm{KMnO}_{4}$ terlihat optimum pada $\mathrm{pH}$ netral sesuai dengan teori, $\mathrm{KMnO}_{4}$ akan teroksidasi menjadi $\mathrm{MnO}^{4-}$ yang masing-masing pada $\mathrm{pH}$ tertentu memiliki nilai $\mathrm{E}^{\mathrm{o}}$ terbesar pada $\mathrm{pH}$ netral-asam. Reaksi $\mathrm{MnO}^{4-}$ yang terurai pada masing-masing $\mathrm{pH}$ terdapat pada persamaan (1) hingga (3).

Kalium permanganat sangat reaktif dalam kondisi yang ditemukan di industri air. $\mathrm{KMnO}_{4}$ akan mengoksidasi berbagai macam zat anorganik dan organik. Kalium permanganat $\left(\mathrm{Mn}^{7+}\right)$ dikurangi menjadi mangan dioksida $\left(\mathrm{MnO}_{2}\right)\left(\mathrm{Mn}^{4+}\right)$ yang mengendap dari larutan ${ }^{[7]}$.

Pada gambar diatas didapatkan nilai penyisihan COD optimum terjadi pada saat $\mathrm{pH}$ netral dengan nilai penambahan oksidator sebesar $0,6 \mathrm{mg} / \mathrm{L}$ sebesar 53\%. Berdasarkan penelitian, nilai COD meningkat namun pada titik tertentu senyawa organik yang didegradasi akan habis sehingga nilai COD akan semakin turun. Sesuai dengan teori ${ }^{[8]}$, peningkatan konsentrasi COD dapat disebabkan oleh tingginya kandungan $\mathrm{KMnO}_{4}$ dalam memutus ikatan karrbon-karbon berantai rangkap pada senyawa organik namun secara tidak menyeluruh yang kemudian terdegradasi dan terbaca kembali sebagai COD.

Penurunan surfaktan pada $\mathrm{pH}$ berbeda 
Selanjutnya penelitian dilakukan dengan menganalisis kandungan dari deterjen yang dioksidasi menggunakan oksidator $\mathrm{KMnO}_{4}$ pada $\mathrm{pH}$ berbeda-beda sebesar 3, 7 dan 9 . Analisis ini menggunakan metode MBAS untuk melihat penyisihan dari surfaktan anionik yaitu LAS dan ABS. Limbah dengan pengkondisian $\mathrm{pH}$ yang berbeda-beda diperlakukan sama dengan penambahan $\mathrm{KMnO}_{4}$ sebanyak 0,6 $\mathrm{mg} / \mathrm{L}, 0.65 \mathrm{mg} / \mathrm{L}$ dan $0.7 \mathrm{mg} / \mathrm{L}$ dengan pengadukan menggunakan jartest dengan kecepatan 90 rpm dan dilakukan selama 30 menit dan pengendapan 30 menit. Hasil dari penelitian dapat dilihat pada Gambar 11. dan Gambar 12. berikut:

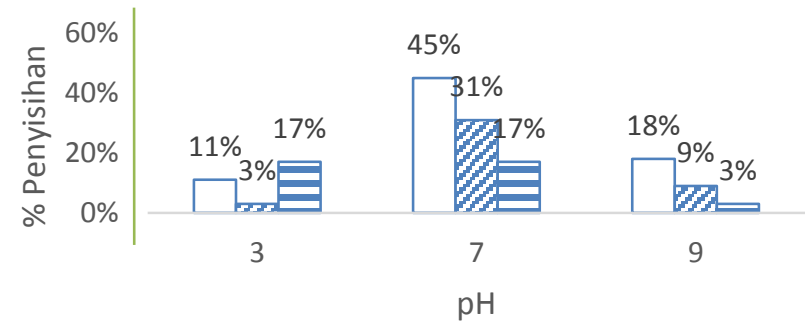

$\square 0,6 \square 0,65 \quad \square 0,7$

Gambar 11. Penambahan $\mathrm{KMnO}_{4}$ terhadap Penyisihan LAS dan $\mathrm{pH}$

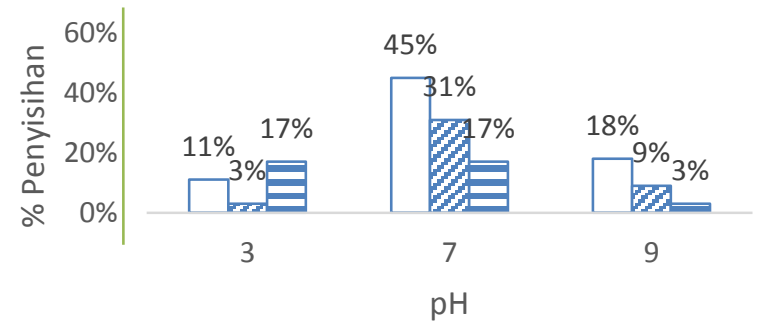

$\square 0,6 \square 0,65 \square 0,7$

Gambar 12. Penambahan $\mathrm{KMnO}_{4}$ terhadap Penyisihan ABS dan $\mathrm{pH}$

Penyisihan LAS optimum pada penambahan $0,6 \mathrm{mg} / \mathrm{L}$ dengan penyisihan sebesar $53 \%$ dan penyisihan ABS optimum dengan penyisihan sebesar $45 \%$ dalam keadaan netral. Hal ini sesuai dengan teori sebelumnya bahwa pada $\mathrm{pH}$ netral asam memiliki nilai $\mathrm{E}^{\mathrm{o}}$ terbesar sehingga penyisihan senyawa organik menjadi lebih optimum, dengan menurunnya senyawa organik ini sekaligus dapat menurunkan surfaktan yang terdapat dalam limbah tersebut.

\section{KESIMPULAN}

Kesimpulan yang diambil dari penelitian ini adalah:

1. Nilai penyisihan COD dan surfaktan dengan menggunakan oksidator $\mathrm{H}_{2} \mathrm{O}_{2}$ optimum pada saat dosis penambahan 0,1 $\mathrm{mL}$ dengan $\mathrm{pH}$ netral hingga didapatkan nilai penyisihan COD sebesar 53\% dan penyisihan LAS dan ABS masingmasing sebesar $39 \%$ dan $33 \%$.
2. Nilai penyisihan COD dengan menggunakan oksidator $\mathrm{KMnO}_{4}$ optimum pada saat penambahan $0,6 \mathrm{~mL}$ dengan $\mathrm{pH}$ netral sehingga didapatkan nilai COD sebesar 58\% dan penyisihan nilai surfaktan berada pada penambahan dosis $0,6 \mathrm{~mL}$ pada $\mathrm{pH}$ netral dengan nilai penyisihan LAS dan ABS masing-masing sebesar 53\% dan 45\%

\section{DAFTAR PUSTAKA}

[1] Santi, L. 1999. Adsorpsi deterjen oleh akar gulma itik (Lemna sp.), Skripsi, Jurusan Kimia FMIPA Unair, Surabaya.

[2] Saifudin. 2005. Fotodegradasi Limbah Detergen dalam Suspensi Semikonduktor TiO2. Jurnal Reaksi (Journal of Science and Technology) Jurusan Teknik Kimia Politeknik Negeri Lhokseumawe Vol. 3 No.6, Desember 2005 ISSN 1693-248X.

[3] Aleboyeh, A., Olya, M.E., Aleboyeh, H. 2009. Oxidative treatment of azo dyes in aqueous solution by potassium permanganate. Journal of Hazardous Materials. 162:1530-1535.

[4] Williams, D.G. The many benefits of hydrogen peroxide. Family Health News [homepage on the internet]. c2003 [diakses 20 Desember 2016]. Available from: http://www.rebprotocol.net/November2007/The\%20Many\%20Benefits \%20of\%20Hydrogen\%20Peroxide.pdf

[5] Ksibi, M. 2006. Chemical Oxidation with Hydrogen Peroxide for Domestic Wastewater Treatment. Laboratoire de L'Eau, de L'Energie et de L' environnement (LEEE), Ecole Nationale d'Ingenieurs de Sfax (ENIS) Universite de Sfax, B.P. W 3038, Sfax, Tunisia. Chemical Engineeringg Journal 119 (2006) 161-165

[6] Elfiana. 2008. Penurunan Konsentrasi LAS dalam Air Terkontaminasi Deterjen Menggunakan Reagen Fenton. Jurnal Teknik Kimia Politeknik Negeri Lhokseumawe.Vol.6 No.11, Juni 2008 ISSN 1693-248X.

[7] Chang, R. 2005. Kimia Dasar Konsep-Konsep Int Edisi Ketiga Jilid 2. Jakarta: Erlangga

[8] Hendratna, A. 2011. The Application of $\mathrm{MnO2}$ and $\mathrm{KMnO4}$ for Persistent Organic Compounds and COD Removals in Wastewater Treatment Process. TRITA-LWR Degree Project 11:01. Departmet of Land and Water Resource Engineering, Royal Institue of Technology (KTH). SE-100 44 Stockhlom, Sweden. 